\title{
Review of: Miltsios, N. \& Tamiolaki, M. (Eds.) (2018). Polybius and his Legacy. Berlin-Boston: De Gruyter. $456+$ i-ix pp.
}

Palabras claves: Polibio - Historiografía - Estudios sobre Recepción

Keywords: Polybius - Historiography - Reception Studies

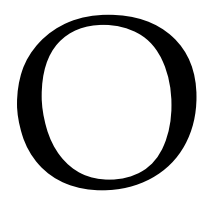

ver the last fifteen years the Histories of Polybius have been attracting the increasing interest of classical scholars. ${ }^{1}$ The present book under review, which was co-edited by N. Miltsios and M. Tamiolaki resulted from a recent international colloquium on the topic, "Polybius and his Legacy: Tradition, Historical Representation, Reception", which was held at Aristotle University of Thessaloniki (Greece) in 2016. The book includes twenty-one papers of researchers both from Europe and USA.

As it is usual with proceedings, the individual papers are linked with each other only to a small extent, and their quality is not always uniform. In a formal aspect, the book opens with a short introduction, which mainly summarizes the content of the collected essays and places them within current Polybian scholarship. ${ }^{2}$ The whole volume is structured in four main sections: 1) "Key Themes and Ideas", with six papers; 2) "Narrative and Structure", four papers; 3) "Intertextual Relationships", five papers; and, 4) "Reception", which closes the book with six contributions. The volume ends with a list of the authors' curricula and a useful general index of names, although an index of cited passages is lacking. Next, I will summarize critically each of the individual contributions of the book.

E. Gruen writes "Polybius and Ethnicity" (pp. 13-34). The author proposes there to explore whether "Polybius' estimate of the 'other' represents judgment on ethnicity" and, especially, if in the Histories is there any idea, or not, of "inferiority of the 'other'", understood as a natural feature (p. 13). The author has wide experience dealing with "otherness". Some years ago Gruen has indeed published Rethinking the Other in Antiquity (2011), a study about barbarism and "otherness" in classical world, in which

\footnotetext{
${ }^{1}$ Among the monographs: Champion (2004); McGing 2010; Baronowski (2011); Maier (2012); Dreyer (2011); Miltsios (2013); Phillips (2016); Moreno Leoni (2017); Sebastiani (2017). Specific proceedings: Santos Yanguas \& Torregaray Pagola (2005); Schepens \& Bollansée (2005); Smith \& Yarrow (2012); Gibson \& Harrison (2013); Grieb \& Koehn (2013). I would like to highlight the unpublished Ph.D. Dissertation of E. Nicholson (2015).

2 The editors point out in p. 1, f.n. 1 to the text of Walbank (2002: 1-27) for a state of the art, but there are some analytical studies worth being read: Thornton (2004; 2004a); Moreno Leoni (2012).
} 
he has sought to break with a well-established view that had been emphasizing for decades the centrality of Greek and Roman prejudices over other societies, and he tried, instead, to redirect the discussion towards the recognition of the ways through which Greeks and Romans had been able in the past to recognize the "others", but also to integrate them. This reading has provided a fresh approach, since it has allowed to limit more extreme past views on the topic. ${ }^{3}$ However, as in the case of his current article, there are some problems with Gruen's arguments, which I would like to treat in some detail below.

On the one hand, the view of Gruen seems to suppose that denying absolute hostility to discourses on the "other" in antiquity necessarily implies the opposite attitude, that is, an inexistence of any hostility between cultures with the omnipresence of cultural understanding and integration through Mediterranean Sea taken for granted. The leap towards a multicultural discourse, which erases power relations in representations of the "other", so much to the taste of American current historiography, is the obvious next step to follow. In this sense, Gruen defends the idea that words usually associated with the language of "barbarism" in the Histories have indeed a neutral meaning there, implying the idea of just recognising something as "non-Greek" in generical terms. The author proceeds from there in a hasty manner denying any negative connotation of barbarism's language through Polybius' work. It is an argument maybe extremely forced, at the least not convincing in some passages. For example, against all the textual evidence, Gruen rejects a Polybian use of the cultural or ethnic negative Celt stereotype. There are of course nuances in Polybius' approach that call for a closer philological approach. The Achaean historian's imaginary world is not indeed one inhabited only by Greeks or Barbarians. It seems to me anyway that there are some misunderstandings in Gruen's view, mainly because of his usually inconsistent conceptual perspective regarding "otherness" (a really wide category, not limited to "ethnic", but including women, children, peasants, poor people). If Polybius' hostility against Celts or Galatians doesn't exist in the Histories, how should we understand passages as 5.111.6-7, in which Prusias of Bithynia is warmly praised for having slaughtered an entire Galatian tribe, including women and children, an action elevated even to the category of an "example" to all Greeks of Asia Minor by the historian? ${ }^{4}$

On the other hand, Gruen's approach to narrative structure seems not to have been sufficiently careful. No one can of course object Gruen's claim that "Polybius plainly does not represent Gauls merely as raving savages" (p. 21). Gauls in the Histories certainly show some rationality, eluding ethnic cliché. But, then, Gruen seeks to accentuate a further positive image when he points to the simple character of this people of northern Italy. Gruen appeals, for instance, to a linear reading of Polybius'

\footnotetext{
${ }^{3}$ Hartog (2003); Isaac (2006). Cf. my review in Nova Tellus.

${ }^{4}$ Gruen mentions this passage in p. 14, f.n. 5, but he says nothing about this issue. It is astonishing how Gruen refuses, adding no further comment, that 3.98.3-4 implies a negative judgement on Abilix's "Spanish and barbaric reasoning" (p. 17).
} 
ethnographic "digression" on Cisalpine Gaul (2.14.4-17.2), which leads him to depict Gauls as a people with "limited means and limited needs" (p. 21), because of geography and not of an "inborn character". No one will argue against this sentence. But "limited needs" is an ingenious addition, because, in fact, Polybius accentuates in his historical narrative not only the lack of means, but he also points out to Celtic greed as a historical causation. Indeed, Polybius affirmed, the Celts had set their eyes with envy (ophthalmiasantes) on the beauty and fertility of the land earlier inhabited by Etruscans and, therefore, they had attacked and expelled them quickly from Po valley (2.17.3). ${ }^{5}$ It does not follow from this account, of course, that Polybian criticism had a "genetic basis", as Gruen well warns us, but this seems quite obvious. What is the usefulness of such an historical analysis? No author in the past, as far as I know, has proposed that Polybius was a racist avant la lettre, whereas it has been many times accentuated, and to my understanding correctly, that the Greek historian had resorted there to the stereotype of northern barbarians and, in so doing, he had explored political issues useful for the benefit of his readers interested in the rise of Roman hegemony over Italy. ${ }^{6}$ Gruen moves away so from the most important topic for the understanding of the work, which is related to what did the historian want to make his readers learn: i. e. how to understand the contrast between Roman political order and barbaric chaos. Most telling is in this sense Polybius' success in dealing with that in book 2 even without almost using the word "Barbarian" in his text, or its many cognates, and just "putting images before readers' eyes" through enargeia.7 Gruen's analysis of Romans, Carthaginians, and Egyptians is quite similar, but here I will not stop at the particular problems inherent to these specific ethnic depictions.

As I have indicated above, the article largely lacks conceptual accuracy. As can be already read in the first page, Gruen refers indistinctly to "ethnicity", "racial element", and "other", but conceptual precision is missing. Even so, the conclusion, regarding how to understand the vision of the "other" in Polybius is clear: "But the differences lay in society, morality, and mores. The historian drew no racial or ethnic lines" (p. 33). It is readily shared, and I fully endorse this view, but this affirmation does not add anything to what is already known, particularly, since the publication of a major book by C. Champion (2004, pp. 43-63), or even since the appearance of the classical article by R. Martínez Lacy (1991).

C. Champion writes the second article, "Polybian Barbarology, Flute-Playing in Arcadia, and Fisticuffs at Rome" (pp. 35-42). It is a short paper, following his analytical perspective just exposed in Cultural Politics in Polybius's Histories (2004), in which the

\footnotetext{
${ }^{5}$ See on Celtic movement from Gaul to Northern Italy, and the connection between Polybius' and Livy's narrations focused on avaritia: Moreno (2017).

${ }^{6}$ Moreno Leoni (2017, pp. 229-248). The Celtic athesia ("inconstancy") is attributed exclusively to Celtic "mercenaries", but Gruen relates to 3.70.4; 78.2, in which Celts are mentioned with Hannibal as allies, not as mercenaries.

${ }^{7}$ On sight and enargeia: Zangara (2007).
}

Anuario de la Escuela de Historia Virtual - Año 10 - Nº 16 - 2019: pp. 162-172. ISSN: 1853-7049 
author studies a passage where it is narrated the triumphal celebration at Rome of L. Anicius Gallus in 166 BCE (30.22.1-12). Champion relates it to the earlier digression on Arcadia in book 4, in which Polybius had explored the role of music as a tool to soften the harsh nature of the Arcadian character (4.20-21). The author agrees with previous scholarship, which has seen this performance of Anicius Gallus as a strategy to compete with the splendour of Aemilius Paullus' contemporary triumph ceremony over Macedon. But at the same time, Champion focuses on the cultural meaning of this picturesque description and he affirms, in a plausible way, that this description can be linked to a surreptitious Polybian critical attitude. In this sense, the episode might be read as Polybius' mockery towards a sign of badly incorporated Hellenism, and simple barbarian behaviour, of a fraction of the conquering elite in a decadent Rome.

It follows then a rather descriptive article, "Polybius and the Tyrants of Syracuse" (pp. 43-54), in which C. Bearzot notices some interest on the part of the Achaean historian in the history of Western Greeks, beyond the scope of his polemic of book 12 against Timaeus of Tauromenium. At the same time, the author observes that this concern might be linked to the decisive role played by the Syracusan dynasty in preventing the Western Achaeans from developing a political system similar to that of the Peloponnesian Achaeans in Hellenistic times. There is no strong textual evidence to support this hypothesis, but Bearzot's final conclusion, in line with what has already been stated by G. Zecchini and M. Gelzer, about the pendular interest of Polybius in Rome and the Peloponnese, it seems to me nevertheless the fruit of incontrovertible evidence.

More stimulating is F. Meier's approach in "Past and Present as paradoxon theôrêma in Polybius" (pp. 55-74), in which he seeks to give meaning to the apparent oxymoron of the proemium (1.1.2). ${ }^{8}$ In effect, paradoxon theôrêma supposes a "theory", or "scientific principle", available to explain what happens in history "contrary to expectation". Thus, history seems to be understood as contingent, with a high degree of openness to the future, which leads Polybius to explore any kind of counterfactual evidence, or specific situations, apparently contrary to historical characters and readers' expectations. This chaos is worsened by the "entropy" of the Mediterranean symploké (or interconnected universal history). The whole system is presented to readers, then, as highly "unpredictable". At the same time, Polybius nevertheless considers that his readers, with the right orientation provided, will be able to discover keys to understand the process, although only at a micro level, without fully understanding the concrete interaction of the individual components. Meier persuasively resorts to a concept taken from biology: "emergence". As Meier wisely observes, Polybius considers that his readers are perfectly able to individualize all the actions and strategies of historical actors, but that the full result is not always rationally predictable: "History is not the result of an equation" (p. 66). Thus, history can be considered both "explicable" and "contrary to expectation" (p. 67); but Polybius wanted his readers to be sensitive to recurrent patterns in history to be

\footnotetext{
${ }^{8}$ Meier's earlier book is a fine piece of Polybian scholarship: Maier 2012.
} 
able to overcome certain degree of uncertainty and, at the same time, to show his readers examples of how historical and personal circumstances can be redefined by the agents themselves.

B. Gibson studies, meanwhile, the function of praise in Polybius' narrative ("Praise in Polybius", pp. 75-101), warning us about its importance within Polybian historical approach. ${ }^{9}$ And L. Hau, in "Being, Seeming and Performing in Polybius" (pp. 103-113), tackles a really interesting topic, as it is the dichotomy in the work between being and seeming, showing us clearly that this dichotomy is a not very stressed one in the Histories. By emphasizing perceptions, in the fragmented gazes of the characters, Hau discovers that, in effect, dokein ("to seem" in Greek) has an absolutely subjective sense, and that these perceptions often precede decision making and the realization of actions in the historical narrative. Thus, taking into account the case of Scipio Aemilianus in book 31, Hau shows us that there is a certain link between his "reputation" and his true character, which reinforces an idea, already explored by Hau in his recent book, that for every ancient historian "being good is likely to stand in better stead than being immoral" (Hau, 2016, p. 273).

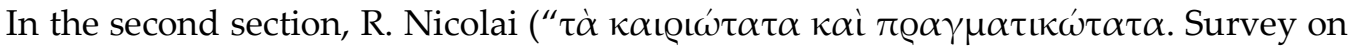
the Speeches in Polybius", pp. 117-130) addresses speeches as important signs to understand the historian's vision. The author focuses on some specific exhortations during battle descriptions, mainly Hannibal at Ticinus as a perfectly opposed pair to P. Cornelius Scipio, who anticipate with their words the later real outcome of the battle. Finally, Nicolai draws attention, in a very convincing way, on the deficiency in current historiographical debate of the dichotomy between reality or invention of those kind of speeches. The author argues that the focus of inquiry should be centred rather than in historicity, on "the function of the speeches within the work and the way of interpreting them", as well as in asking "why and how the historians composed these speeches" (p. 127). In fact, ancient battle exhortations can be understood as a narrative place where it is possible to develop a controlled inventio. The answer, in that sense, should be sensitive to didactics aims, rhetoric, and particularly to the historian's capacity to attend to the dynamic communication established with his audience.

The study of N. Wiater ("Documents and Narrative: Reading the RomanCarthaginian Treaties in Polybius' Histories", pp. 131-165) explores the structure and function of the digression on the treaties between Romans and Carthaginians in book 3, for what he pays close attention to Polybius' careful narrative construction. In fact, Wiater shows us very persuasively that the Achaean historian was able to construct the

\footnotetext{
${ }^{9}$ It is surprising, however, that Gibson insists on the romantic idea that 39.5 is a later addition by a posthumous editor. It reveals a full disregard of a French scholarship, which on the basis of a parallel with the language of contemporary epigraphical register of civic honours, has repeatedly highlighted that the taîs megistais timaîs etimesan auton kata poleis kai zônta kai metallaxanta does not suppose Polybius to be death by then. Many authors have affirmed indeed that the text should have been written by Polybius himself: Veyne (1996, p. 273-274), Heller (2011, p. 292, n.15), Chiricat (2005).
} 
question about the responsibility for the outbreak of the Second Punic War as "a blank space", that, even in the historian's present, was waiting for a solution (pp. 135, 145). Wiater also draws attention, in a very original way, to the parallel between the historian's technical language and that of contemporary inscriptions of Hellenistic interstate arbitrations. The Achaean historian presented his work not only as a resolution of the question, but also presented himself in the shape of an "arbitrator", with his text as a monumentum just like an inscription commemorating a former arbitration. ${ }^{10}$ But the most interesting argument is Wiater's statement about Polybius as wanting "to shape the political and public debate in contemporary Rome" (p. 136). Therefore, I believe that this article is one of the most original and fine contributions to the present volume, since the author achieves an adequate balance between an in-depth analysis of the narrative structure of the work and an attentive approach to the political meanings involved in Polybius' historiographic project. As was clearly pointed out by J. Thornton (2013), the aims of the Achaean historian were not limited to the creation of an artistic work, but to influence in contemporary politics, guiding actively his readers to establish a clear link between past, present, and future. ${ }^{11}$

K. Khellaf writes "Incomplete and Disconnected: Polybius, Digression, and its Historiographical Afterlife" (pp. 167-201), in which it is argued that digression as a practice, although previously attested in Greek historiography from V century BCE, emerges as conscious device in Hellenistic times with Polybius, "who first identified the digression as a necessary element in the historiographical tradition" (p. 176). The argument is interesting and useful also up to section 3, where he discusses the impact of this idea and its reception in Rome as a narrative model. There, his argument is unfortunately supported with little or no textual evidence and, in this reviewer's opinion, it weakens his argument and conclusions (pp. 187-198). ${ }^{12} \mathrm{Ch}$. Baron, meanwhile, addresses in "The Historian's Craft: Narrative Strategies and Historical Method in Polybius and Livy" (pp. 203-221) the issue of narrative differences between book 3 of Polybius and book 21 of Livy, paying close attention to the problem of the location of Ebro River in Polybius' narrative. Baron puts the accent on Polybius' ability to leave clues throughout 3.6-33 in order to let his readers know his implicit rejection of the Roman vision on the location of the river, the city of Saguntum and the causes of the war outbreak, and he does it without doing it openly, as "an attempt at subtle correction of an erroneous tradition" (p. 212). The difference with Livy's history, subtle but significant, also highlights the ability of the Achaean historian to produce a dramatic situation through skilful narrative devices.

\footnotetext{
${ }^{10}$ A good precedent regarding the parallel of Achaean political language and Polybius' one: Köhn (2013).

${ }^{11}$ In fact, Wiater (2016) defends that the story is narrated in such a way to be continually shaped even after the end of narrative. Polybius indeed undermined the telos of his own work and showed an openness to the future: Grethlein (2013).

${ }^{12}$ There is a problem with a typo which might be misleading, when in p. 188, f.n. 62, it is mentioned Philip $\mathrm{V}$ and his campaigns in Sicily. Obviously, the campaigns were in Messenia, not in the island.
} 
In the opening of the third section, with "Polybius and Xenophon: Hannibal and Cyrus the Great as Model Leaders" (pp. 225-239), M. Seretaki and M. Tamiolaki try to look for common themes and linguistic parallels between Xenophon' characterization of Cyrus and Polybius' Hannibal, but the results are rather unconvincing ones. As it happens with the articles of N. Miltsios ("Polybius and Arrian: The Cases of Philip V and Alexander the Great", pp. 325-340), D. Pausch ("Lost in Reception? Polybius' Paradoxical Impact on Writing History in Republican Rome", pp. 357-380), and E. Karakasis ("Silius Italicus and Polybius: Quellenforschung and Silian Poetics", pp. 401415), we could simply refer to Thornton's (2013, pp. 836-837) penetrating observations about this kind reception studies excesses. Regarding some works on Polybius' ancient reception, Thornton clearly explains the preconditions to argue for an intertextuality between two texts. I do not believe, in that sense, that in any of these cases the evidence gathered is strong enough to enable a plausible intertextual reading.

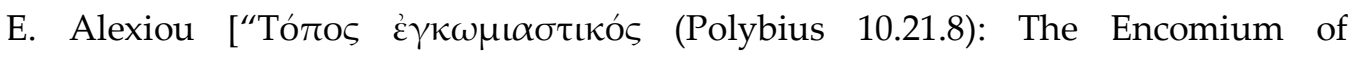
Philopoemen and its Isocratic Background" (pp. 241-255)] approaches the contact between the epidictic genre and Polybius' work, above all regarding Polybius' observations in 10.21 and what Isocrates had written earlier. ${ }^{13} \mathrm{~A}$. Tsakmakis, for his part, discusses the overlapping of the historiographic and biographical genres in Polybius, who, to a large extent, presupposes some of the elements of Plutarch's later practice. In short, the way in which the story narrated and the reality of the reader can be linked in a historiographical text occurs, as is the case of Polybius, in an experiential dimension: "the framing of the story in terms of everyone's experience of human life" (p. 269). Tsakmakis claims for a close reading of the digression on the character of young Scipio Aemilianus and the beginnings of his relationship with Polybius, where "he is presented as the key figure in Scipio's formation" (p. 273)..$^{14}$

G. Parmeggiani ("Polybius and the Legacy of Fourth-Century Historiography", pp. 277-297) examines the conception of history, methodology and aetiology in the Histories and, in accordance with current scholarship on fourth-century fragmentary historiography, he warns us against the misconception of an abrupt cut-off between history writing in Polybius and fourth century BCE historians (Ephorus, Theompompus, Timaeus, etc.). Indeed, currently late-classical and Hellenistic historiography is no longer viewed, as a whole, as a setback and a break with respect to Thucydidean "model" imagined by F. Creuzer and F. Jacoby' classical scholarship..${ }^{15}$ On the contrary,

\footnotetext{
${ }^{13}$ On the relationship between Philopoemen' encomium and the theory of Progymnasmata: Olivera (2017).

${ }_{14}$ A masterful treatment in N. Miltsios (2013, pp. 138-139), who puts the accent on the importance to the Achaean historian of presenting himself as the teacher of Scipio Aemilianus, who also appeared in the famous passage before a burning Carthage (38.21.1-2) as the model reader of the Histories. Cf. with the importance of this association with Scipio in didactical and political terms: Moreno Leoni (2017, pp. 171173).

${ }^{15}$ See: Vattuone (1991); Parmeggiani (2011); Baron (2013), etc. As it happens in the case of F 110 of Ephorus, on the importance of direct research, which was pointed out some years ago by Parmeggiani (2011, p. 114) as a proof of continuity in historiographical methods between fourth and second century: "Una dimensione questa che fa di Eforo e Teopompo dei precursori di Polibio, sul piano della teoria storiografica".
}

Anuario de la Escuela de Historia Virtual - Año 10 - No 16 - 2019: pp. 162-172. ISSN: 1853-7049 
as Parmeggiani shows, far from being able to establish an unmediated link between Polybius and Thucydides' works, attention should be paid more carefully to the fact that the Athenian classical historian had already been read and digested by historians of the fourth century BCE well before Polybius' times, and we know that the Achaean historian was well aware of their works.

The following article, by C. Scardino ("Polybius and Fifth-Century Historiography: Continuity and Diversity in the Presentation of Historical Deeds", pp. 299-321), could well be used as a good counterpoint to the excesses of reception studies we have observed above. Scardino is very clear in his approach when, first of all, taking into account the scarcity of mentions in the Histories to authors of the 5th century BCE (Thucydides, Herodotus), points out that Polybius is more likely not to have been familiar with them, and, second, that it is even possible that the public of the Histories was not familiar either, since Herodotus and Thucydides' most intense reading occurred only from the first century BCE onwards with the rise of "Atticism" in imperial times (p. 309).

It prompts the following reflection by the reviewer: We can reduce all literary theory to the "intertextuality" between specific works, or we can better emphasize similarities, shared models, as part of more or less broad generic options available to authors within their active strategies of literary composition and the possibilities of historical gender understood as shared and negotiated "expectations" with readers. The second path is certainly a safer and more rewarding one. So, whenever we find, for instance, an "ethnographic" account we shouldn't therefore think of an explicit dialogue with Herodotus. Instead, we should seek to recognize concrete strategies to communicate some ideas to readers through narrative and by resorting to different literary formats. ${ }^{16}$ And, in that sense, Scardino's reflection on "an awareness of the genre and of its written and unwritten norms" (p. 313) points out in the same direction. ${ }^{17}$ Formal aspects in ancient historiographical genre do not always need to be related to an explicit influence by a specific author and his work, but, rather, to characteristics and options available to historians within the genre.

B. McGing ("Appian, The Third Punic War and Polybius", pp. 341-356) studies the active reading by Appian of Polybius' narrative of this war and recognizes a negative approach by the historian of Alexandria towards Roman behaviour in that occasion. Th. Biggs ("Odysseus, Rome, and the First Punic War in Polybius' Histories", pp. 381-399), who studies the reception of the Odyssey in Rome and asks how Roman readers could interpret some allusions of Polybius to Odysseus and to the Odyssey in the context of the Roman naval expansion and its first setbacks during the First Punic War. Finally, L. Pitcher ("Polybius and Oscar Wilde: Pragmatics History in Nineteenth Century Oxford", pp. 417-444) studies an unpublished essay by Oscar Wilde during his years as an Oxford

${ }^{16}$ Conte (1994, pp. 105-128); Marincola (1999).

17 In clear allusion to Rossi (1971). 
student, entitled "Historical Criticism Among the Ancients", in which Polybius and his historiographic perspective is prominent in Wilde's methodology and self-fashioning.

To conclude, it can be pointed out that the book edited by Miltsios and Tamiolaki has an uneven quality, typical of conference proceedings. Some contributions, however, do not only have great scholarly quality, but they also provide with fresh readings and interpretations of Polybius' work. These essays make the reading of Polybius and his Legacy a much helpful addition to scholarship on the topic. The editorial quality is very good, since only few errata are noticed, mainly on the dates of publication of various texts in the papers' individual bibliographies. Undoubtedly, classical scholars' interest in Polybius' work has been increased during last years around the world. The present book is a fine addition to it, and its reading will be useful in the future to every people interested in approaching the work of this important Hellenistic Greek historian.

\section{Bibliographical References}

Baron, Ch. (2013). Timaeus of Tauromenium and Hellenistic Historiography. Cambridge: Cambridge University Press.

Baronowski, D. (2011). Polybius and Roman Imperialism. London: Bloomsbury.

Champion, C. (2004). Cultural Politics in Polybius's Histories. Berkeley-Los Angeles: University of California Press.

Chiricat, E. (2005). Funérailles publiques et enterrement au gymnase à l'époque hellénistique (pp. 207-223). In P. Fröhlich and C. Müller (Eds.), Citoyenneté et participation à la basse époque hellénistique. Genève: Droz.

Conte, G. B. (1994). Genres and Readers. Lucretius, Love Elegy, Pliny's Encyclopedia. Baltimore-London: The John Hopkins University Press.

Dreyer, B. (2011). Polybios. Hildesheim-Zurich-New York: Georg Olms.

Schepens, G. and Bollansée, J. (Eds.) (2005). The Shadow of Polybius. Intertextuality as a Reserch Tool in Greek Historiography. Leuven: Peeters.

Gibson, B. and Harrison, T. (Eds.) (2013). Polybius and his world. Essays in memory of F. W. Walbank. Oxford: Oxford University Press.

Grethlein, J. (2013). Experience and Teleology in Ancient Historiography. 'Futures Past' from Herodotus to Augustine. Cambridge: Cambridge University Press.

Grieb, V. and Koehn, C. (Eds.) (2013). Polybios und seine Historien. Stuttgart: Franz Steiner Verlag.

Gruen, E. (2011). Rethinking the Other in Antiquity. Princeton: Princeton University Press.

Hartog, F. (2003). El espejo de Heródoto. Ensayo sobre la representación del otro. Buenos Aires: Fondo Cultura Económica.

Hau, L. (2016). Moral History from Herodotus to Diodorus Siculus. Edinburgh: Edinburgh University Press.

Heller, A. (2011). D'un Polybe à l'autre: statuaire honorifique et mémoire des ancêtres dans le monde grec d'époque impériale. Chiron, 41, 287-312.

Anuario de la Escuela de Historia Virtual - Año 10 - N 16 - 2019: pp. 162-172. ISSN: 1853-7049 
Isaac, B. (2006). The Invention of Racism in Classical Antiquity. Princeton: Princeton University Press.

Koehn, C. (2013). Polybios und die Inschriften. Zum Sprachgebrauch des Historikers (pp. 159-181). In V. Grieb and C. Koehn (Eds.), Polybios und seine Historien. Stuttgart: Franz Steiner Verlag.

Maier, F. (2012). "Uberall mit dem Unerwarteten rechnen". Die Kontingenz historischer Prozesse bei Polybios. C. H. Beck: Munich.

Marincola, J. (1999). Genre, convention and innovation in Greco-Roman historiography (pp. 281-324). In Ch. S. Kraus (Ed.), The limits of historiography: genre and narrative in ancient historical texts. Leiden: Brill.

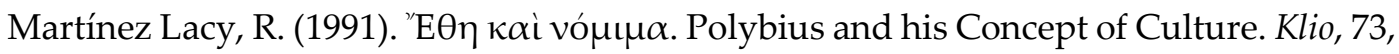
83-92.

McGing, B. (2010). Polybius' Histories. Oxford-New York: Oxford University Press.

Miltsios, N. (2013). The Shaping of Narrative in Polybius. Berlin-New York: De Gruyter.

Moreno Leoni, A. M. (2012). Polibio, el mundo helenístico y la problemática cultural: Algunas líneas de reflexión en los últimos veinte años. De Rebus Antiquis, 2, 123-151.

Moreno Leoni, A. M. (2017). Entre Roma y el Mundo Griego. Memoria, autorrepresentación y didáctica del poder en las Historias de Polibio. Córdoba: Editorial Brujas.

Moreno, A. (2017). Polibio y la digresión sobre la migración gala en el libro V de Tito Livio. Stylos, 26, 160-173.

Nicholson, E. (2015). A reassessment of Philip V of Macedon in Polybios' Histories. (PhD. Dissertation): Newcastle University: Newcastle Upon Tyne.

Olivera, D. (2017). A Filopemén: Historia y retórica en Polibio. AFC, 30 (1), 33-42.

Parmeggiani, G. (2011). Eforo di Cuma. Studi di storiografia greca. Bologna: Pàtron.

Phillips, D. (2016). Polybius Book 1. A Commentary. Ann Arbor: Michigan Classical Press.

Rossi, L. E. (1971). I generi letterari e le loro leggi scritte e non scritte nelle letterature classiche. BICS, 18, 69-94.

Santos Yanguas, N. and Torregaray Pagola, E. (Eds.) (2005). Polibio y la Península Ibérica. Vitoria: Universidad del País Vasco.

Sebastiani, B. B. (2017). Fracasso e verdade na recepção de Políbio e Tucídides. Coimbra: Coimbra University Press.

Smith, C. and Yarrow, L. (Eds.) (2012), Imperialism, Cultural Politics, E Polybius. Oxford: Oxford University Press.

Thornton, J. (2004). Polibio e Roma. Tendenze negli studi degli ultimi anni (I). StudRom, 52 (1-2), 108-139.

Thornton, J. (2004a). Polibio e Roma. Tendenze negli ultimi anni (II). StudRom, 52 (3-4), 508-525.

Thornton, J. (2013). Polibio l'artista. MediterrAnt, 16 (2), 827-842.

Vattuone, R. (1991). Sapienza d'occidente. Il percorso critico di Timeo di Tauromenio. Bologna: Patròn. 
Veyne, P. (1996). Décrets latins de consolation et date de l'édition de Polybe. In A. Chastagnol, S. Demougin, L. Lepelley (Eds.) (pp. 273-280), Splendidissima civitas. Études d'histoire romaine en hommage à François Jacques. Paris: Publications de la Sorbonne.

Walbank, F. W. (2002). Polybian Studies, 1975-2000. In F. W. Walbank, Polybius, Rome, and the Hellenistic World. Essays and Reflections (pp. 1-27). Cambridge: Cambridge University Press.

Wiater, N. (2016). Shifting Endings, Ambiguity and Deferred Closure in Polybius' Histories (pp. 243-265). In A. Lianeri (Ed.), Knowing Future Time in and through Greek Historiography. Berlin-New York: De Gruyter.

Zangara, A. (2007). Voire l'histoire. Théories anciennes du récit historique. Paris: Vrin.

Álvaro M. Moreno Leoni Universidad Nacional de Río Cuarto/ Consejo Nacional de Investigaciones Científicas y Técnicas, Argentina moreno.leoni@gmail.com

Para citar esta reseña:

Moreno Leoni, Álvaro M. (2019). "Review of: Miltsios, N. \& Tamiolaki, M. (Eds.) (2018). Polybius and his Legacy. Berlin-Boston: De Gruyter. 456 + i-ix pp.". Anuario de la Escuela de Historia Virtual, 16, pp. 162-172. 